\title{
SOCIETAL PERCEPTIONS ABOUT BEING A GOOD TEACHER IN LATVIA
}

\author{
Elga Drelinga \\ Daugavpils University, Latvia \\ Sandra Zarina \\ Daugavpils University, Latvia \\ Dzintra Iliško \\ Daugavpils University, Latvia \\ Larisa Silova \\ Daugavpils University, Latvia
}

\begin{abstract}
Teacher is one of the most responsible professions in the world because the teacher builds a sustainable society. There is an ongoing discussion about a professional competency of the teacher and changes in the requirements for teachers in the acquisition of knowledge, skills and attitudes required from teachers. There are numerous researches being carried out about the professional competency of teaching competency. The professional teaching standard that was ratified in 2004 is outdated but the new teaching standard is not designed yet because policy makers cannot come to an agreement about what a good teacher needs to know. For the changes to take place, the main aim of the study is to explore and to analyze societal opinion about the notion of a good teacher and competencies required for a good teacher. The research was carried out from May, 2016 until September with a participation of 160 respondents from different age groups. To ensure the validity of the study the authors used a questionnaire. Acquired data indicate that there exists a significant difference between the opinion expressed by the school age children and the opinion of adults. By describing the ideal of a good teacher pupils pay more attention to personal features of a teacher but adults pay closer attention to the skills and knowledge needed for a teacher.
\end{abstract}

Keywords: competency-based teaching, contemporary teacher, sustainability.

\section{Introduction}

The current global socio-economic and technological conditions put education in the centre of European sustainable competitiveness and development strategy; however, schools experience unprecedented challenges: they need to be able to provide measurable results under the condition of decreased budget, as well as they have to be modern and progressively-minded, 
they have to offer attractive education programs and train young people for jobs that do not exist yet (European Commission/EACEA/Eurydice, 2015). Therefore, teachers need to learn to live in ever changing environment and change themselves. The changes that are taking place towards sustainability are among the driving factor in the University's educational programs (Anspoka, 2014; Pipere, Veisson, \& Salīte, 2015; Jurgena, Cedere, \& Keviša, 2015; Badjanova, J., Iliško, D., \& Drelinga, 2014). First players who are coming across those challenges are the teachers and this depends mainly on them how teacher education serves the needs of young people by teaching them how to solve successfully problems in the complex situations. As this has been acknowledged, the quality of the educational system is closely related to teacher qualification (Barber \& Morushed, 2007). This is expected from the teachers that they offer an opportunity for the younger generation to acquire not only skills but to help youth to learn and to understand diverse aspects of culture, to develop values, sills, attitudes, and survival competencies (Blūma, 2012). What are the skills the teacher needs to acquire to help a young person to become successful at work, family, society and a career? These are the questions of the 21 st century that can be found in numerous researches, scientific articles and discussions (European Commission/EACEA/Eurydice, 2015; OECD, 2005; LIZDA, 2016; MacBeath, 2012; UNESCO, 2016; Vidović \& Domović, 2013; Zariņa, Drelinga, Iliško, \& Krastina, 2016, etc.). The requirements set for the teachers are quite high, but the prestige of the teacher's vocation is quite low. This tendency can be observed in many countries, but especially in Latvia.

On one hand, in 2016 in Latvia there was a wide discussion about the necessity for stricter demands for teachers' selection in the educational programs. At the same time only one percent of the parents participating in the survey expressed the desire for their children to become a teacher (European Commission /EACEA /Eurydice, 2015). If compared to 20 years ago, now there are four times less people becoming teachers that are younger than 32 years (LU, 2015). On the other hand, significant reforms are taking place in Latvia towards competency based approach initiated in 2016 (VISC, 2016), aimed at practical implementation of the competency-based approach in education. At the same time the new teaching standard is not ratified yet, which would describe teachers' tasks, duties and competencies. Therefore, teacher trainers teach skills and competencies that are prescribed in the professional standard of 2004. Society places high expectations on teachers and there are discussions about what a teacher should be like. Pupils and their parents have also developed the image of a good teacher. Latvian populations' opinion could be of high value not only in designing professional standard but also would be valuable for teacher trainers. Therefore, the aim of the article is to explore the opinion of 
Latvian citizens about what qualities and competencies the teacher has to possess.

The analyses of the notion and the content of the "teachers' professional competency" in the research leads the authors to acknowledge that teachers' professional competency is a flexible notion as compared with the knowledge, skills and attitudes that offer pupils to acquire necessary competencies for a changing world. Therefore, this is clear that the answer to the question:" What is the image of a good teacher?" is that there are no universal answers and the policy makers need to undertake the whole responsibility by designing the professional standard. In this article the authors describe the study that was carried out in year 2016 that explores the opinion of multiple stakeholders involved about the image of a good teacher.

\section{Theoretical background}

Research finding on the image of a good teacher by multiple stakeholders are mainly based on a constructivist view of a teacher (Duffy \& Jonassen, 1992) who arranges a learning process in a way that allows pupils to construct their own understanding in a free atmosphere, where learners have an opportunity to interact with peers and teachers, where learners' ideas are central in learning and teachers pose problems of emerging relevance and build learning around children's ideas. Knowledge construction in the classroom becomes a fluid and evolving process concentrating on pupils' interests. Constructivist thinkers envision children as knowledge producers, creators of values and meanings; they engage in a group discussions and build a shared understanding. The teacher is more of a facilitator than an instructor guiding children in the learning process, and they believe in children's capacity to construct meaning (Edwards, 2011; Walsh, 2002). Researchers who tried to explore the image of the teacher and to understand the choice of pedagogical approach have studies teachers' beliefs, thought, values that have an impact of the professional development (Tatar, 2014)

Similar research in teachers' image has been carried out by Kalke and Baranova (2015) at the University setting and paid particular attention to personal properties and traits of character.

\section{Teachers' professional competency: theoretical aspects and description of the situation}

As noted by Conway, Murphy, Rath and Hall (2009) the understanding about the teacher's professional competency is changeable and it depends on various factors, for example, on society's understanding about educational aims 
and teaching, on the prestige of the profession teacher, on material resources, social context, on the culture, the existing traditions, etc. At the time when there is a reorientation to competency-based approach taking place in the education system, which is aimed at teaching skills to an internationally competitive, knowledge based society, the question about what a good teacher should be like has become especially important, and this is being studied in numerous researches, scientific articles and discussions (Caena, 2011; Hattie, 2003, EK, 2011; EK, 2013; IZM, 2011; UNESCO, 2016; Vidović \& Domović, 2013 et.al.).

At the level of the European Union it is admitted, that member states need to have a united view on the teacher training process and further education. Thus in the suggestions designed in Europe a special attention paid to the content of teacher's professional competency (EK, 2011; EK, 2013; European Commission/EACEA/Eurydice, 2015). It is being related to a wide range of knowledge, skills and attitudes, for example, knowledge in pedagogy, psychology, information technology and the area of the subject, evaluation, inclusive education, design of education programs, leading group work, metacognitive and classroom arrangement skills, planning skills, organisational skills, ability to adjust and evaluate teaching process, ability to cooperate, apply various materials and technologies, to carry out research, be willing to participate, continue education and reflect on it, etc. (EK, 2013). In terms of teachers' training policy issues, the contents of teachers' professional competency is actualised also at the level of UNESO. Thus, for example, in in the discussion organised in Bangkok in 2016 "Valuing Teachers, Improving their Status" (UNESCO, 2016) the content of teacher training and further education was discussed. The following conclusions were drawn: (1) the four spheres of teacher's professional competency shall be included in teacher training programmes: the cognitive sphere (knowledge in the sphere of the subject, pedagogy and information technology); physical sphere (classroom arrangement and communicative skills); spiritual sphere (ethical and moral values); emotional area (compassion and understanding about the different needs of pupils); (2) in the professional development of teachers an important role is played in personal interest and joint responsibility, as well as mutual cooperation, which takes place not only among colleagues, but also at community and international level.

By defining the notion "teachers' professional competency" and by analysing its content, it is noted in research of different levels, that teacher's professional competency is a holistic totality of knowledge that can be developed in a flexible cooperative environment, as well as a totality of skills, attitudes and values, that corresponds to the specific national context and ensures that pupils have the opportunity to acquire the necessary competency for life in a changing world. Thus, it is clear, that there is not one universal answer 
to the question "What a good teacher should be like?" and that responsible for the contents of teachers' professional competency are the policy makers of every country. They have to design the Profession standard and have to include in it specific information on what knowledge, skills and attitudes the teacher shall have.

Unfortunately, in Latvia the work started in 2010 is still in process and the new Standard for the profession of teacher is not ready yet. Thus, teachers, teacher trainers and teachers of further education still use the document approved in 2004, where the necessary knowledge and skills for pedagogical work are defined. It does not correspond to the tendency in the education policy of the European Union, where about the teachers' professional qualification this is discussed at the level of competency. In the present situation, pedagogical programme directors and implementers at Latvian higher education institutions, as well as teachers of further education are forced to follow the suggestions by the European Union, where the teachers' professional competency is discussed in general. Whereas, the opinion about a good teacher based on the nation context can be found in researches, where the existing opinions in Latvian nation are being studied, for example, in the research "Study of needs of further education of pedagogues, 2011" (IZM, 2011) the surveyed pupils, teachers and parents admitted that they want the teacher to be tolerant, objective, with good professional knowledge in his/her subject and psychology, he/she has to be a charismatic leader, creative and modern - open to everything new. The teacher also needs to have a good command of foreign languages and has to be able apply multiform methods. He/she has to know how to use information technology; he/she has to be exhaustively educated, positive, exciting/inspiring, honest, with good communication and cooperation skills, ready to continuously improve his/her knowledge.

Further in the article there is described the research carried out in 2016, where Latvian citizens of different age were surveyed and the opinion about a good teacher based in their personal experience was found out.

\section{Research methodology}

Date obtained in a research that was carried out during March - September, 2016 is analysed in the present article. The aim of the research is to evaluate the opinion of multiple stakeholders about the image of a good teacher. The authors used a questionnaire as a quantitative research methodology. Among the research participants were 160 randomly selected respondents. Among them were $\mathrm{N}=40$ preschool children (average age 5 years), $\mathrm{n}=40$ pupils (average age 14 years), $\mathrm{n}=40$ young people (average age 22 years), $\mathrm{n}=40$ adults (average age 45 years). The questionnaire contains the following question: "Please, describe 
the image of a good teacher." The answers were recorded and later transcribed. For the purpose of the study the authors used the content analysis.

\section{Data obtained in the research and interpretation}

As a result of the content analyses the authors have identified four themes: (1) The opinion of preschool pupils (5-7 years old) about the image of a good teacher; (2) the opinion of pupils (8-18 years old) about a good teacher; (3) The opinion of youth (19-25 years old) about a good teacher; (4) The opinion of adults ( 26 years old and up) about a good teacher.

\section{The analyses of the opinion of multiple stakeholders}

\section{The opinion of the 5-7 years old children about a good teacher}

In the upbringing of pre-school children one the significant factors is considered to be the emotional aspect (Līduma, 2014; Liegeniece, 1996; Lieǵeniece, 1999). Pre-school children expressed their opinion in relation to teacher's human characteristics, such as necessity for love "she is like a mother, she hugs", necessity for sensitivity and understanding "she ...she rebukes..., then she is sad." There is a need for loving relationships as expressed in children's responses. Particular attention is paid to teacher's appearance. She needs to be "beautiful and strong." The participants emphasized teacher's skills to make the whole educational process engaging and interesting "...the main thing is, that it is interesting". Teacher needs to have various skills "...the teachers has to know how to do different things". Among the significant skill, pupils consider teacher's competency to communicate with pupils. she "...plays with us", "...reads fairy tales", "...gives us sweets if we perform well", and "...gives home work".

\section{The opinion of the 8-18 years old children about a good teacher}

In the educational system children have an urgent need for a physical and psychological security, the basics of which are trustful relationships with adults and peers, positive self esteem, help provided for the personality development (Svence, 1991; Puškarevs, 2001). Most of the features describe the teacher as a personality. Teacher can "...make comments", can build trustful relationships, and build relationships on a mutual respect. Pupils desire to learn in a friendly atmosphere, "...to ask questions in a secure environment," "...have fun together". They want their teacher to be creative, to motivate pupils "...to praise, if there is a good reason for it." At the same time contemporary children who grew in the era of technologies, know how to proceed information, if needed, process huge amount of information, communicates with peers not only in a native language but also un foreign languages, know about new technologies (Anspoka, 2014). Children have also acknowledged such features 
of a good teacher that can be related to teachers' professional competency: knowledge about a wide range of topics, "ability to discuss not only about the mathematics, physics but to also to be able to discuss a wide range of issues: "events that are taking place in the world," "to know languages," "...to know how to use IT," "to be knowledgeable, and to be open to new things, to be able to experiment."

\section{The opinion of youth $19-25$ years old about a good teacher}

At this age this issue of particular importance becomes a question about further life perspectives and plans. Therefore, the main emphases in the evaluation of a good teacher lies on teacher's ability to organize the educational process and a development of such skills as critical thinking, ability to make decision, to develop a tolerant and responsible attitude towards oneself, society, ability to work in teams and to adjust to ever changing marked requirements (Latvia Strategy of a Sustainable Development until 2030, 2010). Youth expect the teacher to see each child's individual abilities. Good teacher trusts in the abilities of children, inspires them and helps them to reach aims. A significant feature of a teacher is his/her ability to help pupils to learn and to gain new experience. They want the teacher to be skillful in teaching, can praise for a well performed job, and motivates pupils for the learning process in a comprehensive way. Youth evaluate positively teachers' experience “...experienced in many spheres". They respect teachers who have a competency not only in their subject matter, who "...is a professional," who "has a good command in one's subject matter," who is "good in a psychology," and has "a good classroom management skill, but isn't too strict." At the same time teacher is "understanding and kind" and "understands pupils". Young people describe a good teacher as the one who is inclusive, "humanistic," who has a good command of communication skills with children and their parents. A good teacher can organize the learning process according to the contemporary requirements and knows how to motivate pupils. The teacher "loves her/his work", "finds an opportunity to differentiate his/her work by finding the key to every heart", "believes in child's abilities"

\section{The opinion of adults (26 years old and up) about a good teacher}

The main features in describing adults' opinion about the image of a good teacher are influenced by the memories from their schooling, and from the images they perceive from media about a prestige of the teacher's vocation and personality. (Research about prestige of teacher's vocation and possibilities to raise it as viewed by various stakeholders, 2007). The parents pay closer attention to teacher's features when their child has completed a preschool and prepare to start their learning process at school (Sobkin, Ivanova, \& Skobel'tsina, 2013). Adults view a good teacher as the one who knows how to build trustful relationships. A good teacher in the one who knows how to build 
trustful relationships. For the pre-school children this is a person who can initiate a play, is joyful, respects pupils' interests, and cooperates with children's' parents. Adults evaluate positively such characteristics of the teacher as an ability to understand pupils and their parents. There is a strong emphases of the factors determining motivation of a teacher to work in his/her vocation despite of a low salary. Adults describe a good teacher as the one with "a good sense of humor" "stylish, well dressed," "patient," and "with a good self respect and a respect towards pupils," the one "who controls his/her language." A good teacher is the one who is eager "to pursue one's education," who motivates pupils, and who "develops in his/her learner's willingness to live and to gain new experience" and teaches "how to reach their aims." Particular attention has been paid to teacher's professional competency "to explain everything in a way that one can learn," who has classroom management competency, can "discipline so that all can learn."

\section{Features of a good teacher as described by multiple stakeholders}

The respondents of different ages have different opinion about teachers. The authors of this research trace similar features that were repeated in diverse age groups of respondents (see Chart 1)

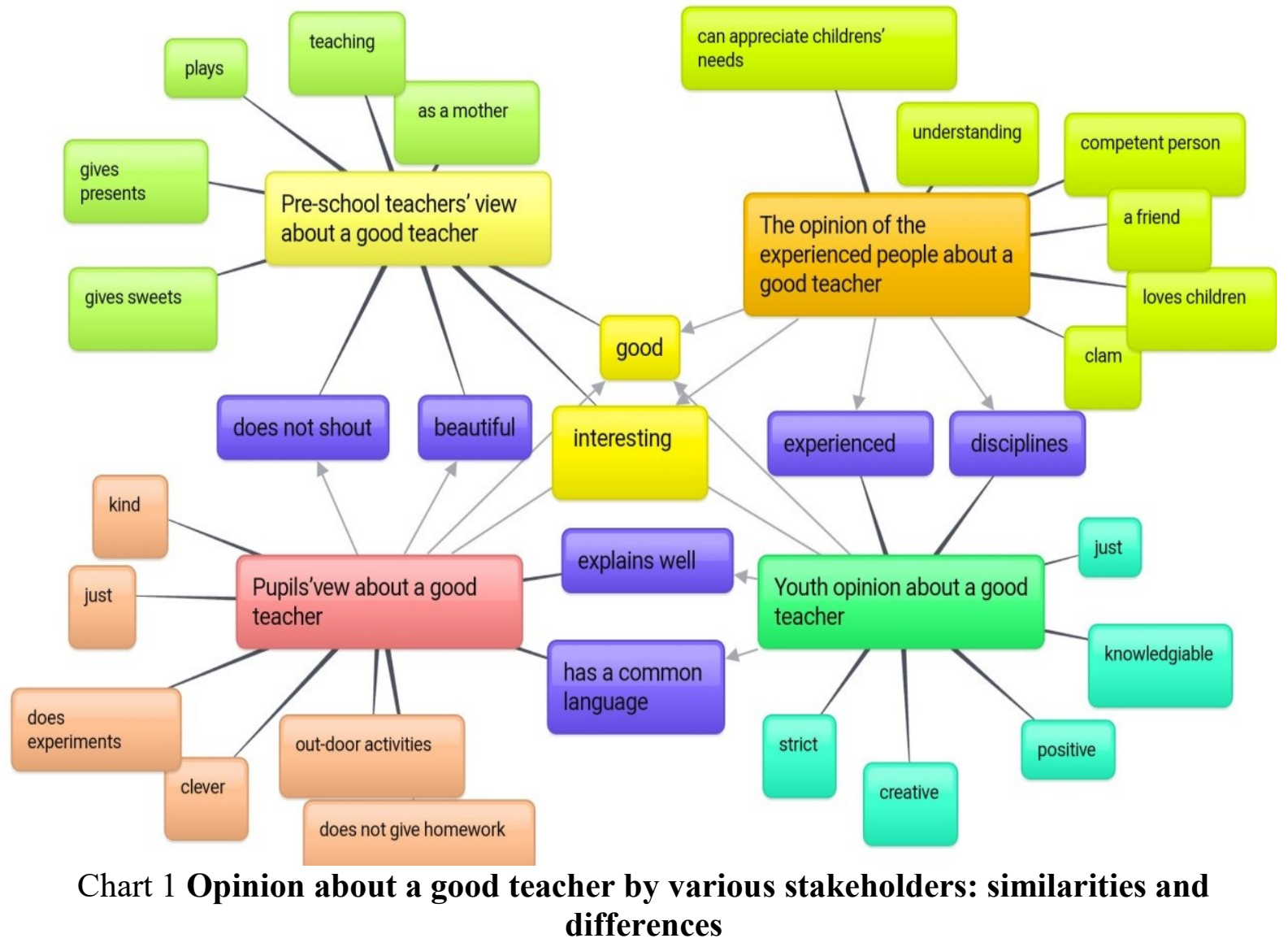


Different stakeholders describe a good teacher by paying close attention to the following features:

Individual characteristics of a teacher: Preschool children want to see their teacher being loving, kind, calm and joyful; youth and adults want to see their teacher as positive, patient, supportive and with a good sense of humor. Particularly important is teachers' attitude towards his/her job. For the preschool children this is a person who plays with them and cares about them. For the school age pupils this is important that the teacher loves his/her job, is able to motivate and inspire, does more than is in his/her workload, for example, organises excursions and discos All multiple stakeholders think that a good teacher is the one who is knowledgeable - clever, educated and with whom one can discuss various issues. This is a teacher, who knows many languages, knows how to use technologies, is not afraid to do new things, and is ready to learn. The respondents involved in this study acknowledged that teachers' appearance also matters. Preschool pupils want a beautiful teacher, school age pupils want to see a contemporary teacher and adults want to see a stylish and well-dressed teacher. A good teacher is the one who knows how to establish cooperation and trustful relationships with others. Preschool children and school age children want to see a teacher who can play with them, participate in different events, can communicate and have fun with them. Parents as important consider such features as respect towards pupils, does not impose his/her opinion, is communicable, and has a good relationship with parents. Among the other highly evaluated skills parents also mentioned classroom arrangement skills - the ability to create a productive environment in the classroom. According to them, a good teacher is honest, does not rise his/her voice, however when there is need for that, he/she can rebuke. All stakeholders expect a discipline in the classroom. Teacher needs to develop pupils' skills and talents and to maintain a good discipline. Both, youth and adults desire their teacher to trust the talents of children, to motivate them for setting new aims and reaching them. An important characteristic of a good teacher is the ability to induce child's willingness to learn and the skill to help him/her to learn and accumulate new experience. If preschool children want to see a good teacher who can praise then, adults have a more detailed requirement that they set for their teacher, for example, teaching in a comprehensive way.

\section{Conclusions and discussions}

While describing the image of a good teacher the participants of the research pay attention to 1) individual features of a good teacher, 2) positive attitude towards work; 3) good knowledge and skills, 4) appearance; 5) ability to build trustful relationships; 6) having good classroom arrangement skills, 
7) skills of developing individual talents by developing each students' individual skills, 8) having an ability to motivate each child for studies and acquisition of a new experience. The view of pre-school children, youth, children and adults about a good teacher are similar, it expands with a respect of an experience and age peculiarities. In the responses of the preschool children particular attention is being paid to teachers' personal features, character, motivated attitude towards work, knowledge, and skills. The responses of youth and adults reflect teachers' skills to see and to develop children individual skills, talents and ability to teach and to develop children's' needs to study. Latvian inhabitants who participated in the research describe a good teacher by paying attention to such features of character as being lovely, calm and joyful. Young people and adults want to see their teacher as positive, responsive, with a good sense of humor. For the research participants particularly important is teacher's attitude towards one's work. Pre-school children view an ideal teacher as the one who plays and cares about them. The school age children express their need to view the teacher who loves one's work, who is motivated and who does more than it is required, as well as organizes out-door activities for children. Both, pupils and young people consider good teacher to be clever, educated and holistically thinking - the one with whom one can discuss various issues, who knows languages, knows IT and who is not afraid to do something new and to learn something new. Latvian inhabitants pay close attention to teacher's appearance. Pupils want to see their teacher as a contemporary person with a good style. Participants involved in this study highly evaluate teachers' classroom management skills-ability to build positive learning environment, honesty. All participants, preschool children, youth and adults expect a discipline and at the same time they do not want to be humiliated. The research data reveal that knowledge about the subject matter is not the main competency required for the teacher by the society. This conclusion relates the research done by the Eurydice carried out in 2015: "Teacher's vocation in Europe: practice, perception of a vocation and politics." (European Commission/EACEA/Eurydice, 2015) The authors of the document state that teachers are well prepared to teach their subject matter. At the same time teachers need more support for introducing innovations and changing their pedagogical practice, as well as for a management of pupils' behavior and a career, in designing individual educational programs with gifted children and children with special needs by designing multicultural environment. The research contains societal opinion about the development of a societal opinion teacher education and professional developmental programs, by including not only issues related to teachers 'professional development but also paying attention to teachers' professional characteristics and attitudes. 


\section{References}

Anspoka, Z. (2014). Tradicionālais un inovatīvais mūsdienu pedagoǵiskajā procesā: dažas problēmas un risinājumi [Traditional and innovative in the pedagogical process nowadays: Some problems and solutions]. Proceedings of the International Scientific Conference "Society. Integration. Education", 1, 347-355.

Badjanova, J., Iliško, D., \& Drelinga, E. (2014). Holistic approach in reorienting teacher education towards the aim of sustainable education: The case study from the regional university in Latvia. Procedia-Social and Behavioural Sciences, 116, 2931-2935.

Barber, M., \& Mourshed, M. (2007). How the world's best-performing school systems come out on top. Retrieved on 15th January 2017 from:

http://mckinseyonsociety.com/downloads/reports/Education/Worlds_School_Systems_F inal.pdf.

Blūma, D. (2012). Izglīîiba un panākumi. Izglìtības attīstības tendences 21. gadsimtā [Education and achievements. Developement of education in the 21st century] $12-19$. Retrieved on 9th August 2016 from http://profizgl.lu.lv/pluginfile.php/36134/ mod_resource/content/0/1_modulis/LU_1.modulis_izgl_attist_21.gs.pdf.

Caena, F. (2011). Literature review Teachers' core competences: requirements and development. Retrieved on 11th November 2016 from http://ec.europa.eu/ dgs/education_culture/repository/education/policy/strategic-framework/doc/teachercompetences_en.pdf

Conway, P., Murphy, R., Rath, A., \& Hall, K. (2009). Learning to teach and its implications for the continuum of Teacher Education: a nine-country cross-national study. Retrieved on 15th December 2016 from http:/www.teachingcouncil.ie/en/Publications/ Research/Documents/Learning-to-Teach-and-its-Implications-for-the-Continuum-ofTeacher-Edu.

Duffy, T. M., \& Jonassen, D. H. (1992). Constructionism: New implications for instructional technology. In T. M. Duffy \& D. H. Jonassen (Ed.). Constructionism and the technology of instruction: A conversation, (pp. 1-16). Hillsdale, NJ: Lawrence Erlbaum.

Edwards, C. (2011). Teacher and learner, partner and guide:The role of the teacher. In C. Edwards, L. Gandini, and G. Forman (Ed.). The hunderd languages of children:The Regio Emilia experience in transformaton. 3rd ed. (pp. 147-172), Santa Barbara, CA.

European Commission (EK). (2011). Policy approaches to defining and describing teacher competences. Retrieved on 15th December 2016 from http://ec.europa.eu/ dgs/education_culture/repository/education/policy/strategic-framework/doc/definingteacher-competences_en.pdf

European Commission (EK). (2013). Supporting teacher competence development for better learning outcomes. Retrieved on 15th December 2016 from http://ec.europa.eu/ dgs/education_culture/repository/education/policy/school/doc/teachercomp_en.pdf.

European Commission/EACEA/Eurydice (2015). The teaching profession in Europe: practices, perceptions, and policies. Eurydice Report. Luxembourg: Publications Office of the European Union.

Hattie, J. (2003). Teachers make a difference. What is the research evidence? Australian Council for Educational Research conference, October 2003. Retrieved on 11th November 2016 from http://research.acer.edu.au/cgi/ viewcontent .cgi?article= $1003 \&$ context $=$ research_conference_2003.

Izglītības un zinātnes ministrija (IZM). (2011). Pedagogu tālakizglītības vajadzību izpēte [Study of needs of further education of pedagogues] Retrieved on 11th November 2016 
from http://petijumi.mk.gov.lv/sites/default/files/file/IZM_Petijums_par_pedagogu_ talakizglitibas_vajadzibam_2011_maijs.pdf.

Jurgena, I., Cedere, D., \& Keviša, I. (2015). Innovative and traditional elements in the work of academic staff: the Views of pre-service teachers. Journal of Teacer Education for Sustainability, 17 (2), 74-91.

Kalkge, B., \& Baranova, S. (2015). Image of the University faculty in the view of student teahers. Proceedings of the International Scientific Conference "Society. Integration. Education", 1, 186-197.

LIZDA. (2016). Teacher in the middle of numerous challenges - changes the teaching profession is undergoing in higher institutions taht trains teachers Retrieved on 9 December 2016 from http:// http://www.lizda.lv/?jaunums=1502.

Latvijas Universitāte (LU). (2015). Konceptuālā diskusija par skolotāju izglītību Latvijā. [Conceptual discussion about teacher training in Latvia] Retrieved on 15th December 2016 from http://www.izm.gov.lv/images/aktualitates/2015/10122015/LU_1012 2015.pdf.

Latvijas ilgtspējīgas attīstības stratēgija lìdz 2030. gadam (2010). [Strategy for sustainable development of Latvia till 2030] Retrieved on 11th November 2016 from http://www.pkc.gov.lv/images/LV2030/Latvija_2030.pdf.

Līduma, A. (2014). Bērnu attīstības iespējas pirmsskolas izglītības pedagoǵiskajā procesā. [Opportunities for preschool children to develop in the pedagogical process] Education Reform in Comprehensive School: Education Content Research \& Implementations Problems, 33-45.

Lieǵeniece, D. (1996). Kopveseluma pieeja 5-7 gadus veca bērna audzināšanā. [Holitic approach in the upbringing of the 5-7 years old children]. Liepāja: LPA.

Lieǵeniece, D. (1999). Kopveseluma pieeja bērna audzināšanā [Holisic approach in the upbringing of children]. Rīga: RaKa.

MacBeath, J. (2012). Future of Teaching Profession. Retrieved on 11th November 2016 from http://download.ei-ie.org/Docs/WebDepot/EI\%20Study\%20on

$\% 20$ the $\% 20$ Future $\% 20$ of $\% 20$ Teaching\%20Profession.pdf.

OECD. (2005). Teachers Matter - attracting, developing and retaining effective teachers. Retrieved on 9 December 2016 from http://www.oecd.org/edu/ preschoolandschool/34990905.pdf.

Pêtījums par pedagogu profesijas prestižu un iespējām to paaugstināt dažādu mērḳauditoriju skatījumā (2007). [Research about the prestige of teaching vocation and a possibility to raise it as viewed by various groups $f$ population] Retrieved on 15th December 2016 from from: https://www.researchgate. net/publication/259534439_PETIJUMS_PAR_ PEDAGOGU_PROFESIJAS_PRESTIZU_UN_IESPEJAM_TO_PAAUGSTINAT_DA ZADU MERKAUDITORIJU SKATIJUMA

Pipere, A, Veisson, M., \&Salīte, I. (2015). Developing research in teacher education fir sustainability: UN DESD via Journal of Teacher Education for Sustainability. Journal of Teacher Education for Sustainability, 17 (2), 5-44.

Puškarevs, I. (2001). Attīstības psihologija [Developemental psychology] Rīga: RaKa.

Sobkin, V., Ivanova, A., \& Skobelitsina, K. (2013). The Attitudes of Preschoolers' Parents Toward School Education. Russian Education \& Society, 55 (7), 79-89.

Svence, G. (1991). Attīstības psihologija [Developmental psychology] Rīga: Zvaigzne ABC.

Tatar, N. (2014). Pre-service teachers' beliefs about the image of a science teacher and science teaching. Journal of Baltic Science Education, 14 (1), 34-44. 
UNESCO. (2016). Valuing Teachers, Improving their Status. Retrieved on 9 December 2016 from http://www.unescobkk.org/fileadmin/user_upload/apeid/TeacherEducation/WTDOct2016 BGK/WTD_Forum_2016_Summary_Report.pdf

Valsts izglīî̄bas satura centrs (VISC). (2016). Kompetenču pieeja mācību saturā [Competency approach in the educational content] Retrieved on 12 November 2016 from http://visc.gov.lv/visc/projekti/dokumenti/esf_831_prezent.pdf.

Vidović, V., \& Domović, V. (2013). Teachers in Europe - Main Trends, Issues and Challenges. Croatian Journal of Education,15, 3/2013, 219-250 Retrieved on 11th November 2016 from https://bib.irb.hr/datoteka/670665.CJE_Vol_15_Sp_Ed_No_3 2013_Vizek_Vidovic_Domovic4.pdf.

Walsh, D. J. (2002). Constructing an artistic self: A cultural perspective. In L. Bresler \& M. Thompson (Ed.). The arts in children's' lives: Context, culture, and curriculum, (pp. 101-111). The Netherlands: Springer.

Zariņa, S., Drelinga, E., Iliško, Dz., \& Krastiņa, E. (2016). Teacher's Vocation and Students' Attitudes Towards a Choice of Teacher's Vocation. Proceedings of the International Scientific Conference "Society. Integration. Education," 1, 265 - 274. 